\title{
Xanthochromia Measurement
}

National Cancer Institute

\section{Source}

National Cancer Institute. Xanthochromia Measurement. NCI Thesaurus. Code C147449.

The determination of the amount of xanthochromia present in a sample. 